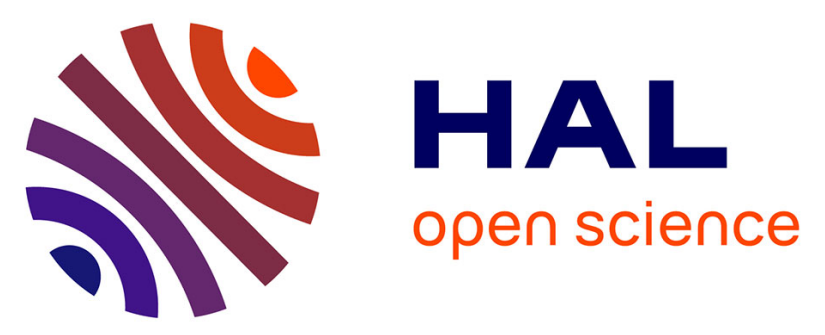

\title{
Backbone Cyclization Turns a Venom Peptide into a Stable and Equipotent Ligand at Both Muscle and Neuronal Nicotinic Receptors
}

\author{
Julien Giribaldi, Yves Haufe, Edward Evans, Muriel Amar, Anna Durner,
} Casey Schmidt, Adèle Faucherre, Hamid Moha Ou Maati, Christine Enjalbal, Jordi Molgó, et al.

\section{To cite this version:}

Julien Giribaldi, Yves Haufe, Edward Evans, Muriel Amar, Anna Durner, et al.. Backbone Cyclization Turns a Venom Peptide into a Stable and Equipotent Ligand at Both Muscle and Neuronal Nicotinic Receptors. Journal of Medicinal Chemistry, 2020, 10.1021/acs.jmedchem.0c00957 . hal-02995265

\section{HAL Id: hal-02995265 https://hal.science/hal-02995265}

Submitted on 30 Sep 2021

HAL is a multi-disciplinary open access archive for the deposit and dissemination of scientific research documents, whether they are published or not. The documents may come from teaching and research institutions in France or abroad, or from public or private research centers.
L'archive ouverte pluridisciplinaire HAL, est destinée au dépôt et à la diffusion de documents scientifiques de niveau recherche, publiés ou non, émanant des établissements d'enseignement et de recherche français ou étrangers, des laboratoires publics ou privés. 


\title{
Backbone cyclization turns a venom peptide into a stable and equipo- tent ligand at both muscle and neuronal nicotinic receptors
}

\author{
Julien Giribaldi1 ${ }^{1 \dagger}$, Yves Haufe ${ }^{2 \dagger}$, Edward R. J. Evans ${ }^{3}$, Muriel Amar ${ }^{4}$, Anna Durner², Casey Schmidt ${ }^{3}$, \\ Adèle Faucherre ${ }^{5}$, Hamid Moha Ou Maati ${ }^{5}$, Christine Enjalbal ${ }^{1}$, Jordi Molgó ${ }^{4}$, Denis Servent ${ }^{4}$, David \\ T. Wilson ${ }^{3}$, Norelle L. Daly33, Annette Nicke² and Sébastien Dutertre*1
}

${ }^{1}$ Institut des Biomolécules Max Mousseron, UMR 5247, Université de Montpellier, CNRS, 34095 Montpellier, France.

2Walther Straub Institute of Pharmacology and Toxicology, Faculty of Medicine, LMU Munich, Nußbaumstraße 26, 80336 Munich, Germany.

${ }^{3}$ Centre for Molecular Therapeutics, Australian Institute of Tropical Health and Medicine, James Cook University, Cairns, QLD 4878, Australia.

4Université Paris-Saclay, CEA, Département Médicaments et Technologies pour la Santé (DMTS), SIMoS, ERL CNRS 9004, F-91191 Gif sur Yvette, France.

5Département de Physiologie, Institut de Génomique Fonctionnelle, CNRS/INSERM UMR 5203, Université de Montpellier, 34095 Montpellier, France.

\begin{abstract}
Venom peptides are promising drug leads, but their therapeutic use is often limited by stability and bioavailability issues. In this study, we designed cyclic analogues of $\alpha$-conotoxin CIA, a potent muscle nicotinic acetylcholine receptor (nAChR) blocker with significantly lower affinity at the neuronal $\alpha 3 \beta 2$ subtype. Remarkably, all analogues retained the low nanomolar activity of native CIA towards muscle-type nAChRs but showed greatly improved resistance to degradation in human serum and, surprisingly, displayed up to 52 -fold higher potency for the $\alpha 3 \beta 2$ neuronal nAChR subtype (IC ${ }_{50} 1.3 \mathrm{nM}$ ). Comparison of NMR-derived structures revealed some differences that might explain the gain of potency at $\alpha 3 \beta 2 \mathrm{nAChRs.} \mathrm{All}$ peptides were highly paralytic when injected into adult zebrafish and bath-applied to zebrafish larvae, suggesting barriercrossing capabilities and efficient uptake. Finally, these cyclic CIA analogues were shown to be unique pharmacological tools to investigate the contribution of the presynaptic $\alpha 3 \beta 2$ nAChR subtype to the train of four (TOF) fade.
\end{abstract}

\section{Introduction}

Natural extracts from animals, plants and bacteria provide one of the richest sources of bioactive peptides, some of which have entered clinical development for the treatment of human diseases such as diabetes, HIV, hepatitis and cancer. Animal venom peptides are of particular interest, as they have been finely tuned by millions of years of preypredator coevolution to potently and selectively target receptors involved in key physiological functions and, consequently, they are widely employed as potent pharmacological probes ${ }^{1}$. Cone snails are predatory marine mollusks that have evolved and radiated into more than 800 different species and nowhere is peptide diversity more apparent than within their venom ${ }^{2}$. They have developed extremely potent and fast acting neurotoxic venoms mainly composed of small peptides (10-40 residues) called conotoxins. These conotoxins are generally highly constrained by disulfide bridges (2-4 bridges), and target a wide range of receptors with key physiological functions for rapid prey immobilization and defense 3,4 . Disulfide bridges provide conotoxins with rigid conformations, enabling a tight and specific interaction with their molecular targets, which are mainly ion channels, but also transporters and G protein-coupled receptors ${ }^{5,6}$.
Members of the $\alpha$-conotoxin subfamily specifically block the nicotinic acetylcholine receptors (nAChRs) ${ }^{6,7}$. nAChRs are ligand-gated ion channels of primary importance in the peripheral and central nervous systems, where they intervene in a wide range of physiological and pathophysiological processes, including muscle contraction, pain sensation, nicotine addiction, and neurological disorders such as Parkinson's and Alzheimer's diseases ${ }^{6}$. These receptors exist as homopentamers or heteropentamers composed of a large variety of homologous subunits. Subunits $\alpha 2-\alpha 10$ and $\beta 2-\beta 4$ assemble into the diverse group of neuronal nicotinic receptors, while the muscle-type nicotinic receptor exists only as adult $(\alpha 1)_{2} \beta 1 \varepsilon \delta$ and fetal $(\alpha 1)_{2} \beta 1 \gamma \delta$ subunit combinations 8. $\alpha$-Conotoxins are classified according to the number of residues within the loops formed by two conserved disulfide bridges. Interestingly, in most cases, the size of the loops seems to determine their specificity for different nAChR subtypes. Thus, 3/4 $\alpha$-conotoxins target homomeric neuronal nAChRs, 3/5 $\alpha$-conotoxins target muscle-type nAChRs and 4/4, 4/6 and 4/7 $\alpha$-conotoxins target different heteromeric and/or homomeric neuronal nAChRs ${ }^{6}$.

Despite great advances in peptide synthesis and drug development, the direct utilization of conotoxins as therapeutics is limited because of their poor bioavailability, mostly 
due to amide bond breakdown by digestive enzymes, as well as their high polarity and molecular weight, which restrict their intestinal absorption. Thus, alternative routes of application, such as intrathecal administration, have been developed ${ }^{9}$. However, head-to-tail cyclization, $\mathrm{N}$-acetylation and C-amidation are widely employed strategies to improve peptide stability through prevention of degradation by aminopeptidases and carboxypeptidases ${ }^{10}$. Although $\mathrm{N}$ acetylation and $\mathrm{C}$-amidation are relatively easy to implement via chemical techniques, the more challenging headto-tail cyclization is often preferred because it results in an increased permeability through biological barriers ${ }^{11,12}$.

Whereas cyclization was previously shown to improve the stability of several $\alpha$-conotoxins with specificity for neuronal nAChRs ${ }^{13-17}$, backbone cyclization of a paralytic, muscle-type $3 / 5 \alpha$-conotoxin has not been reported before. Here we describe the synthesis, pharmacological characterization, and structure determination of three cyclic analogues of the muscle-type $\alpha$-conotoxin $\alpha$-CIA and demonstrate their increased stability and altered subtypes selectivity. In addition, we show how their unique selectivity profile can be used to study the weakening of the muscle during repetitive nerve stimulation (fading of muscle twitches during the "train of four" repetitive stimulation pattern).

\section{Results}

The previously described $\alpha$-conotoxin CIA ${ }^{18}$ from the predation-evoked venom of Conus catus is a highly potent blocker of muscle-type nicotinic receptors. It has a typical $3 / 5 \alpha$-conotoxin disulfide framework (Cys1-Cys3; Cys2Cys4) and displays high sequence homology with other known muscle-type conotoxins. However, contrary to other $3 / 5 \alpha$-conotoxins, it also shows activity at the $\alpha 3 \beta 2$ neuronal subtype. Interestingly, the NMR structure of $\alpha$-CIA revealed a relatively short inter-termini distance of about 10 $\AA$ A that favors head-to-tail cyclization (Figure 1A). Therefore, we investigated the effect of backbone cyclization of this peptide with amino acid linkers of different lengths (Figure 1B). The objective of this modification was to produce the first proteolysis-resistant and highly potent blocker of both neuronal and muscle-type nicotinic receptors, representing a unique pharmacological tool.

\section{Chemical synthesis of cyclic $\alpha$-conotoxin CIA analogues}

After anchoring of the C-terminal residue on a chloro-(2'chloro) trityl resin, elongation of the peptide chain was performed manually using Fmoc-based SPPS (Solid Phase Peptide Synthesis) ${ }^{19,20}$. Mild cleavage conditions were used to allow the separation of the peptide from the resin without affecting the side-chain protecting groups. The crude protected peptide was cyclized under coupling conditions 21 . Side-chain deprotection and subsequent purification produced the cyclic peptide. Next, a regioselective folding strategy using acetamidomethyl (Acm) protecting groups (Cys ICys III) was employed to produce the disulfide bond connectivity of the native peptide ${ }^{18}$. After final purification, the homogeneity of folded cCIA peptides was assessed by analytical RP-HPLC-UV coupled to ESI-MS (Figure 1C and Supplementary Figure 1). 
A

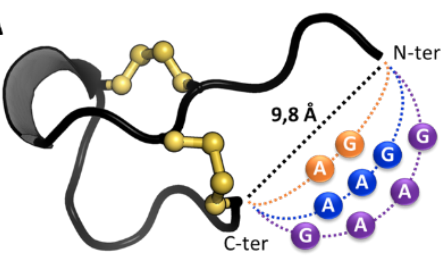

B

CIA

CCIA-2

CCIA-3

CCIA-4
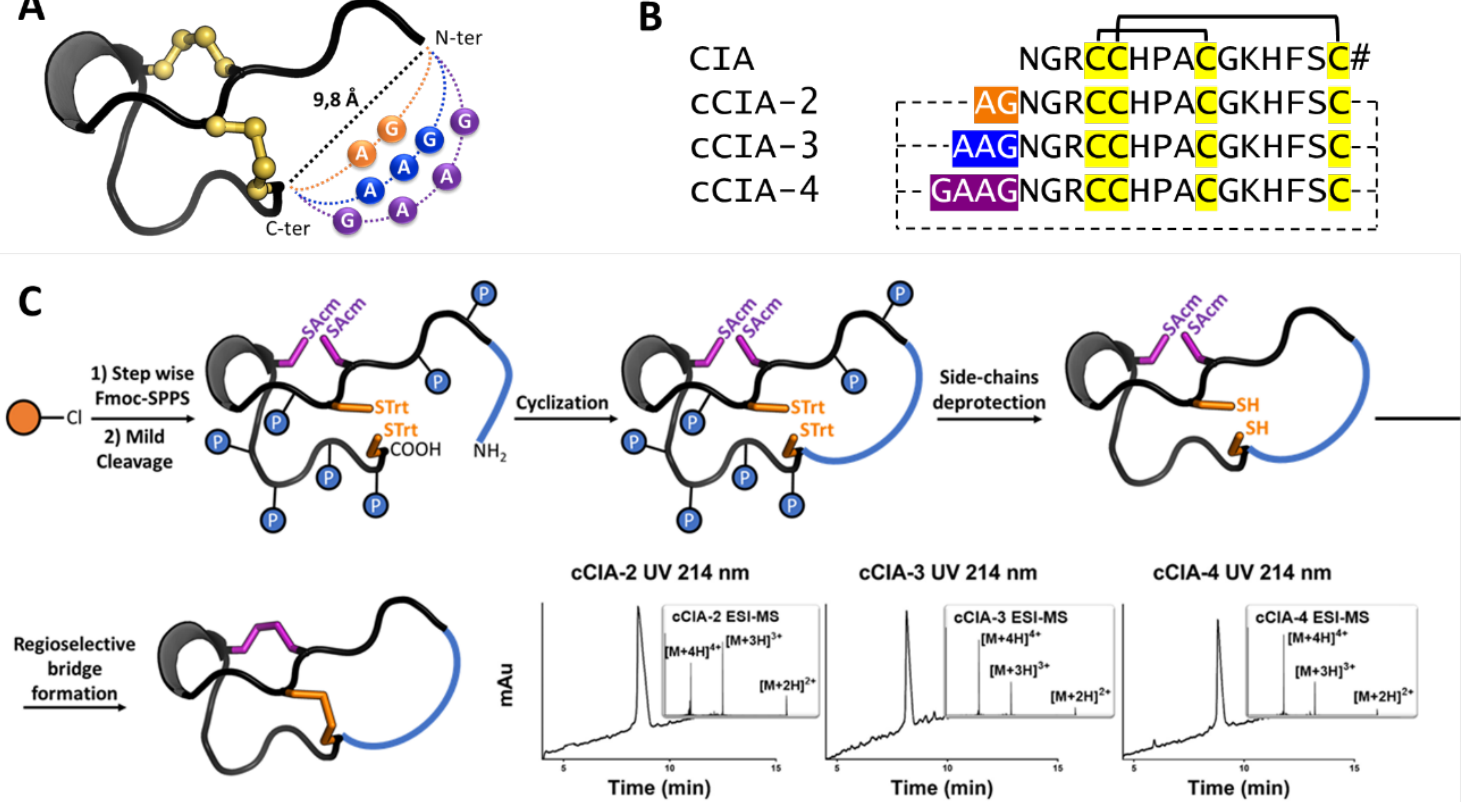

Figure 1. Sequences and chemical synthesis strategy for $\alpha$-conotoxin CIA cyclic analogues (cCIAs). (A) NMR structure (backbone representation) of CIA. CIA exhibits a classical $\alpha$-conotoxin fold with Cys I-Cys III and Cys II- Cys IV disulfide connectivity (represented in yellow). (B) Based on the inter-termini spacing, amino acid linkers with a length between 10 and 19 $\AA ̊$ were designed. Symbol \# indicates an amidated C-terminal residue. (C) Strategy for the synthesis of three cyclic $\alpha$-CIA peptides and the respective RP-HPLC/ESI-MS analysis to confirm purity $>95 \%$. The orange round circle represents a PS-chloro(2'-chloro) trityl resin and P represents common side chains protecting groups used in Fmoc-SPPS. RP-HPLC-UV (ACN gradient from 0 to $30 \%$ in $30 \mathrm{~min}$ ) coupled to ESI-MS analyses revealed the presence of dominant peaks of the expected masses.

\section{Electrophysiology and binding assays}

The inhibitory potencies of the cCIA peptides were investigated using the two-electrode voltage-clamp method on rat $\alpha 3 \beta 2$ neuronal nAChRs subtypes and fetal rat muscletype $\mathrm{nAChR}\left((\alpha 1)_{2} \beta \gamma \delta\right)$ expressed in Xenopus laevis oocytes. All three cyclic analogues retained the low nanomolar ( $\mathrm{IC}_{50}$ 4-9 $\mathrm{nM}$ ) potency of the native toxin ( $\mathrm{IC}_{50} 6.6 \mathrm{nM}$ ) at the fetal muscle-type nAChR (Figure 2A). Surprisingly, cyclization significantly improved the potency of CIA (IC $5068.2 \mathrm{nM}$ ) ${ }^{\psi}$ at the $\alpha 3 \beta 2$ subtype with up to 52 -fold increase in potency for the most active analogue cCIA-3 ( $\mathrm{IC}_{50} 1.3 \mathrm{nM}$, Figure 2B). Thus, $\alpha$-cCIA- 3 is the first highly potent blocker that displays low nanomolar $\mathrm{IC}_{50}$ values for both the neuronal $\alpha 3 \beta 2$ subtype and the muscle-type nAChRs.

As the potency increase at the $\alpha 3 \beta 2$ receptor was accompanied by a slower recovery of the receptor from the block, we next measured the dissociation of the toxin from both muscle-type and $\alpha 3 \beta 2 \mathrm{nAChR}$ subtypes. Despite the similar potency of CIA and cCIA analogues on the muscle-type nAChR, the cyclic analogues displayed significantly slower off-rates with cCIA-3 having the smallest dissociation constant ( $\left.\mathrm{K}_{\text {off }}\right)$ and a wash-out time of $\approx 30 \mathrm{~min}$ to reach $80 \%$ recovery of ACh-induced current responses (Figure $2 \mathrm{C}$ and Supplementary Figure 2) at the muscle-type nAChRs. In contrast, complete dissociation from neuronal $\alpha 3 \beta 2$ subtypes occurred within seconds and could not be determined with the established protocol. Therefore, the real-time receptor reactivation during a $10 \mathrm{~s}$ agonist application (Supplementary Figure 3-4) was analyzed and compared to provide an estimate of the dissociation of the cCIA analogues from this receptor. Again, this revealed that cCIA-3 has the slowest dissociation rate. As many $\alpha 3 \beta 2$-selective $\alpha$-conotoxins show a rather high affinity at the $\alpha 3 \beta 2$ binding site and alternative $\alpha$-conotoxin binding sites have been suggested, we wondered whether cCIA-3 may bind to an allosteric binding site at the $\alpha 3 \beta 2$ receptor. However, functional competition binding experiments with $\alpha$-conotoxin MII, a potent competitive antagonist at the $\alpha 3 \beta 2$ subtype, showed that preincubation with $100 \mathrm{nM}$ cCIA-3 inhibited binding of MII, a result consistent with a competitive binding of cCIA3 to the orthosteric $\alpha 3 \beta 2$ binding site (Supplementary Figure 5). The potency of $\alpha$-cCIA-3 was further evaluated on several nAChR subtypes. Responses in the presence of 10 $\mu \mathrm{M}$ of cCIA- 3 were $80 \%$ or higher for rat $\alpha 2 \beta 2, \alpha 2 \beta 4, \alpha 3 \beta 4$, $\alpha 4 \beta 2, \alpha 4 \beta 4$ and human $\alpha 9 \alpha 10$ neuronal nAChRs, demonstrating no significant inhibitory activity (Supplementary Table 1). Only weak activity was detected at the human $\alpha 7$ subtype at $10 \mu \mathrm{M}$ (65\% of response). Remarkably, however, cCIA-3 readily blocked the $\alpha 6 / \alpha 3 \beta 2 \beta 3$ subtype and the adult muscle $\mathrm{nAChR}$ with $\mathrm{IC}_{50 \mathrm{~s}}$ of $8.64 \mathrm{nM}$ and $184 \mathrm{pM}$, respectively (Supplementary Figure 6A-B). The recovery of block from cCIA appears more than twice as slow for the human adult nAChR (Koff: $0.013 \mathrm{~min}^{-1}$ vs $0.03 \mathrm{~min}^{-1}$ ) compared to the fetal nAChR (Supplementary Figure 7). 
A

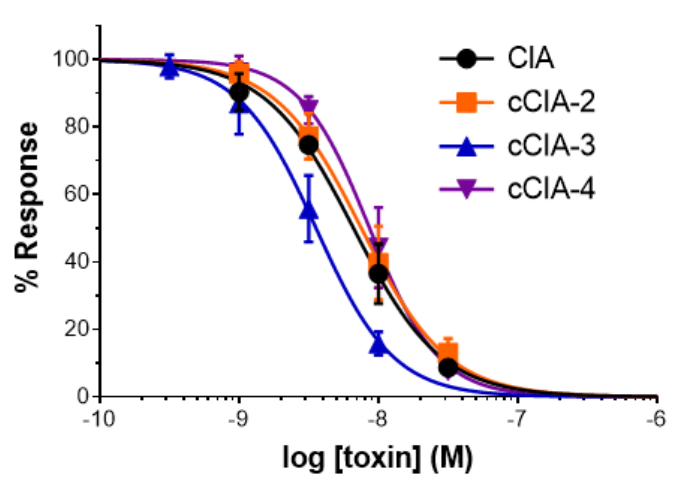

C

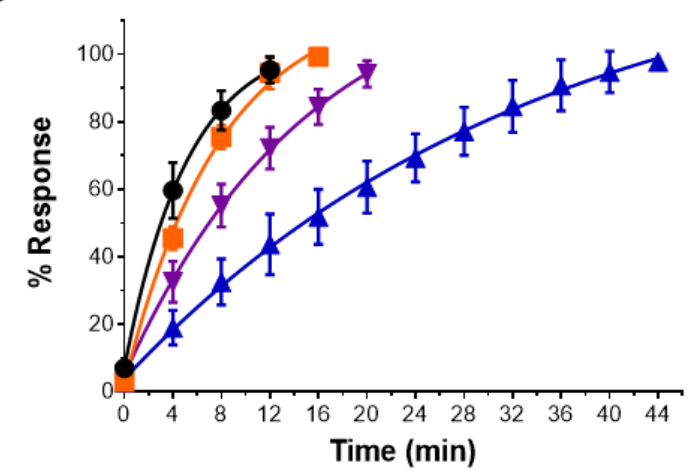

B

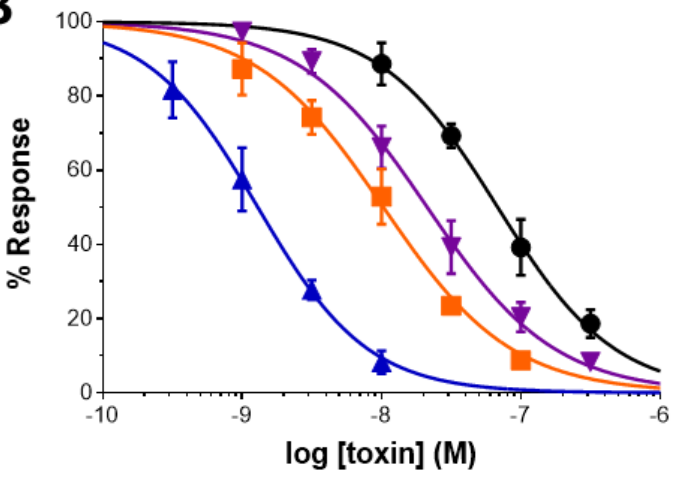

D

\begin{tabular}{|c|c|c|c|c|c|c|}
\hline \multirow[b]{2}{*}{ Toxin } & \multicolumn{3}{|c|}{$(\alpha 1)_{2} \beta \gamma \delta$} & \multicolumn{3}{|c|}{$\alpha 3 \beta 2$} \\
\hline & $\begin{array}{l}\text { Koff } \\
\left(\mathrm{min}^{-1}\right)\end{array}$ & $\begin{array}{l}\mathrm{IC}_{\mathrm{s0}} \\
(\mathrm{nM})\end{array}$ & $\begin{array}{c}\text { Hill } \\
\text { slope }\end{array}$ & $\begin{array}{c}\text { Koff } \\
\left(\mathrm{min}^{-1}\right)\end{array}$ & $\begin{array}{l}I_{50} \\
(\mathrm{nM})\end{array}$ & $\begin{array}{l}\text { Hill } \\
\text { slope }\end{array}$ \\
\hline CIA & $\begin{array}{c}0.191 \\
(0.144- \\
0.245)\end{array}$ & $\begin{array}{c}6.62 \\
(5.69- \\
7.67) \\
\end{array}$ & $\begin{array}{c}1.385 \\
(1.706- \\
1.134)\end{array}$ & D & $\begin{array}{c}68.22 \\
(58.86- \\
79.13) \\
\end{array}$ & $\begin{array}{c}1.036 \\
(1.231- \\
0.869)\end{array}$ \\
\hline $\begin{array}{c}\mathrm{CClA}- \\
2\end{array}$ & $\begin{array}{c}0.126 \\
(0.102- \\
0.151)\end{array}$ & $\begin{array}{c}7.54 \\
(6.47- \\
8.77)\end{array}$ & $\begin{array}{c}1.407 \\
(1.762- \\
1.138)\end{array}$ & N.D & $\begin{array}{l}10.33 \\
(9.01- \\
11.83)\end{array}$ & $\begin{array}{c}0.948 \\
(1.102- \\
0.818)\end{array}$ \\
\hline $\begin{array}{c}\text { CClA- } \\
3\end{array}$ & $\begin{array}{r}0.030 \\
(0.020- \\
0.039)\end{array}$ & $\begin{array}{r}3.57 \\
(3.07- \\
4.14)\end{array}$ & $\begin{array}{c}1.569 \\
(1.957 . \\
1.280)\end{array}$ & N.D & $\begin{array}{c}1.30 \\
(1.11- \\
1.51)\end{array}$ & $\begin{array}{r}1.104 \\
(1.314- \\
0.928)\end{array}$ \\
\hline $\begin{array}{c}\mathrm{CClA}- \\
4\end{array}$ & $\begin{array}{c}0.066 \\
(0.044- \\
0.089)\end{array}$ & $\begin{array}{c}8.64 \\
(7.41- \\
10.01)\end{array}$ & $\begin{array}{c}1.756 \\
(2.464 \\
1.339)\end{array}$ & N.D & $\begin{array}{c}21.3 \\
(18.87 \\
24.09)\end{array}$ & $\begin{array}{c}0.952 \\
(1.068- \\
0.849)\end{array}$ \\
\hline
\end{tabular}

Figure 2. CIA cyclic analogues retain potency at the muscle-type nAChR and show increased affinity at $\alpha 3 \beta 2 \mathrm{nAChRs}$. Dose-response curves of CIA and the three cyclic analogues (cCIA-2, cCIA-3, and cCIA-4) on (A) rat muscle-type and (B) neuronal $\alpha 3 \beta 2 \mathrm{nAChRs.} \mathrm{Xenopus} \mathrm{laevis} \mathrm{oocytes} \mathrm{expressing} \mathrm{the} \mathrm{indicated} \mathrm{receptors} \mathrm{were} \mathrm{analyzed} \mathrm{by} \mathrm{two-electrode} \mathrm{voltage-clamp}$ at $-70 \mathrm{mV}$ holding potential. Responses to $2 \mathrm{~s}$ pulses of $100 \mu \mathrm{M}$ ACh were recorded after 3 min preincubation with the respective toxin. (C) Recovery of muscle-type nAChRs from toxin block measured in 4 min intervals. Each point represents the mean of measurements from at least three different oocytes. Error bars represent S.D. (D) Summary of inhibition and dissociation constants of the toxins. Numbers in brackets are $95 \%$ confidence intervals. N.D. $=$ not determined.

\section{NMR spectroscopy}

High-resolution NMR spectroscopy allowed the determination of three-dimensional structures of the CIA cyclic analogues (Figure 3A). Two-dimensional TOCSY, NOESY, COSY and HSQC spectra were collected for all three CIA cyclic analogues and the assignments made using standard approaches 22 (Supplementary Table 2). Structures were determined based on the NOE data, and angle restraints predicted from TALOS ${ }^{23}$. Additional peaks are present in the cCIA-2 and cCIA-4 spectra, most likely representing alternative conformations, whereas cCIA-3 has primarily one set of peaks corresponding to a single conformation. Therefore, the linker length appears to impact on the structural stability. The dominant conformations were assigned for the peptides and a superposition of the structures with native $\alpha$-CIA is shown in Figure 3B, highlighting the similarity between the cyclic analogues and the native peptide. The most striking structural deviation is within residues 10-14 of CIA, where the root mean square deviation (RMSD) values of the backbone atoms with their corresponding atoms in the cyclic analogues equate to $1.67 \AA, 4.28 \AA$ and $4.10 \AA$ for cCIA2 , cCIA-3 and cCIA-4 respectively. 
A
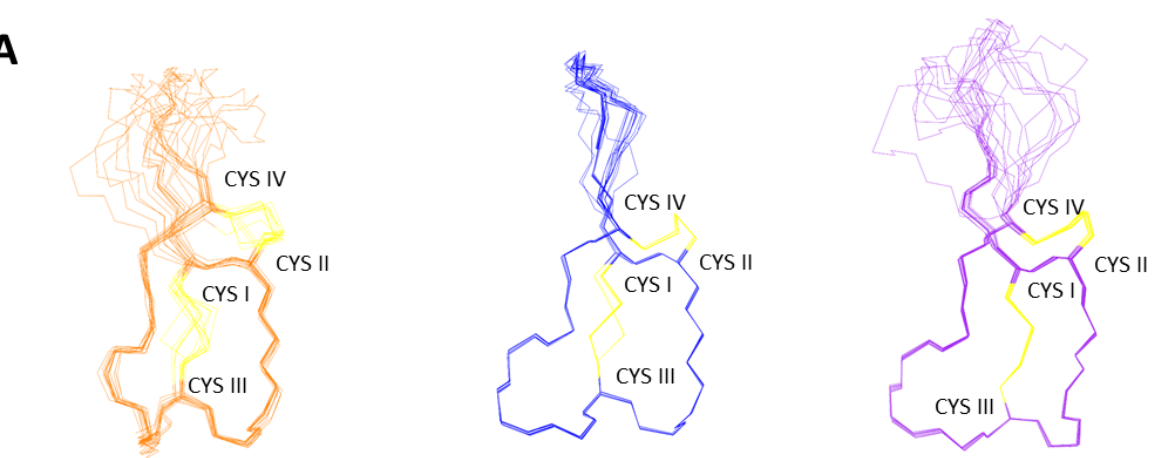

B
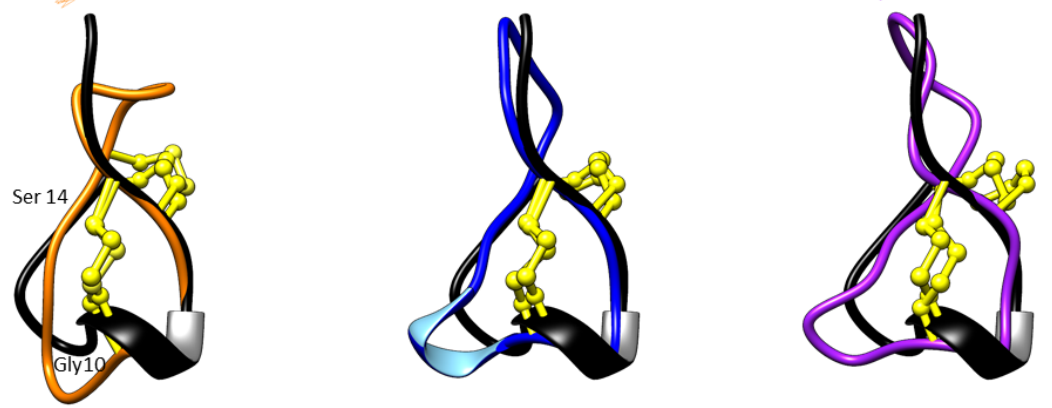

Figure 3. NMR-derived structures of the cyclic CIA analogues. (A) The 15 lowest energy structures are superimposed over the backbone atoms for residues 6-17 (cCIA-2; orange, left), 4-18 (cCIA-3, blue, middle) and 5-19 (cCIA-4, mauve, right), and the disulfide bonds are shown in yellow ball and stick representation. (B) cCIA-2 (left), cCIA-3 (middle) and cCIA-4 (right) superimposed over $\alpha$-CIA backbone atoms (black) for residues 3-17 (cCIA-2), 4-18 (cCIA-3) and 5-19 (cCIA-4).

\section{Serum stability assay}

The stability of CIA and its cyclic analogues towards enzymatic degradation was determined by incubation with human serum AB. Peptides were incubated for $8 \mathrm{~h}$ at $37^{\circ} \mathrm{C}$ and the amount of intact peptide remaining was determined by liquid chromatography/MS analysis of aliquots taken at $0,1,2,4,8 \mathrm{~h}$ post-incubation. As shown in Figure 4A, the degradation kinetics of the cyclic analogues were much slower than that of CIA, especially during the first $3 \mathrm{~h}$. cCIA4 showed the highest resistance to serum degradation, with up to $70 \%$ intact peptide remaining after $8 \mathrm{~h}$ of incubation. In comparison, cCIA-2 and cCIA-3 have half-life values of $440 \mathrm{~min}$ and $320 \mathrm{~min}$, respectively. Finally, degradation of native $\alpha$-CIA was the fastest, with a half-life of $80 \mathrm{~min}$. Thus, CIA cyclization greatly improved ( $\geq 4-6$-fold) the resistance against enzymatic degradation, consistent with previously published data on conotoxin cyclization 13-17.

Zebrafish in vivo assays
Prior to investigating a potential oral/transcutaneous uptake of CIA and its three cyclic analogues, we first performed in vivo intramuscular injections into adult zebrafish (Danio rerio) to evaluate the potency in this species. Intramuscular injection of $\alpha$-conotoxin CIA and its three cyclic analogues produced a rapid flaccid paralysis of skeletal muscle, as evidenced by a loss of an upright posture of the fish, and ultimately complete immobilization. Paralysis induced by CIA and CCIA analogues exhibited a dose-dependent effect, with IC ${ }_{50}$ values for CIA, cCIA-2, cCIA-3 and cCIA4 of $6.88 \mu \mathrm{M}, 12.1 \mu \mathrm{M}, 57.87 \mu \mathrm{M}$, and $76.22 \mu \mathrm{M}$, respectively (Figure 4B). This evaluation of paralysis caused by muscle nAChR blockade led to investigation of the oral/transcutaneous toxin uptake by tracking the movement of zebrafish larvae in $100 \mu \mathrm{M}$ toxin for $1 \mathrm{~h}$ using the ZebraBox tracking system (Figure 4C). Consistent with the intramuscular injection data, native CIA and cCIA-2 induced a strong paralysis, suggesting efficient uptake of these toxins, whereas cCIA-3 and cCIA-4 were less potent (Figure 4D). 

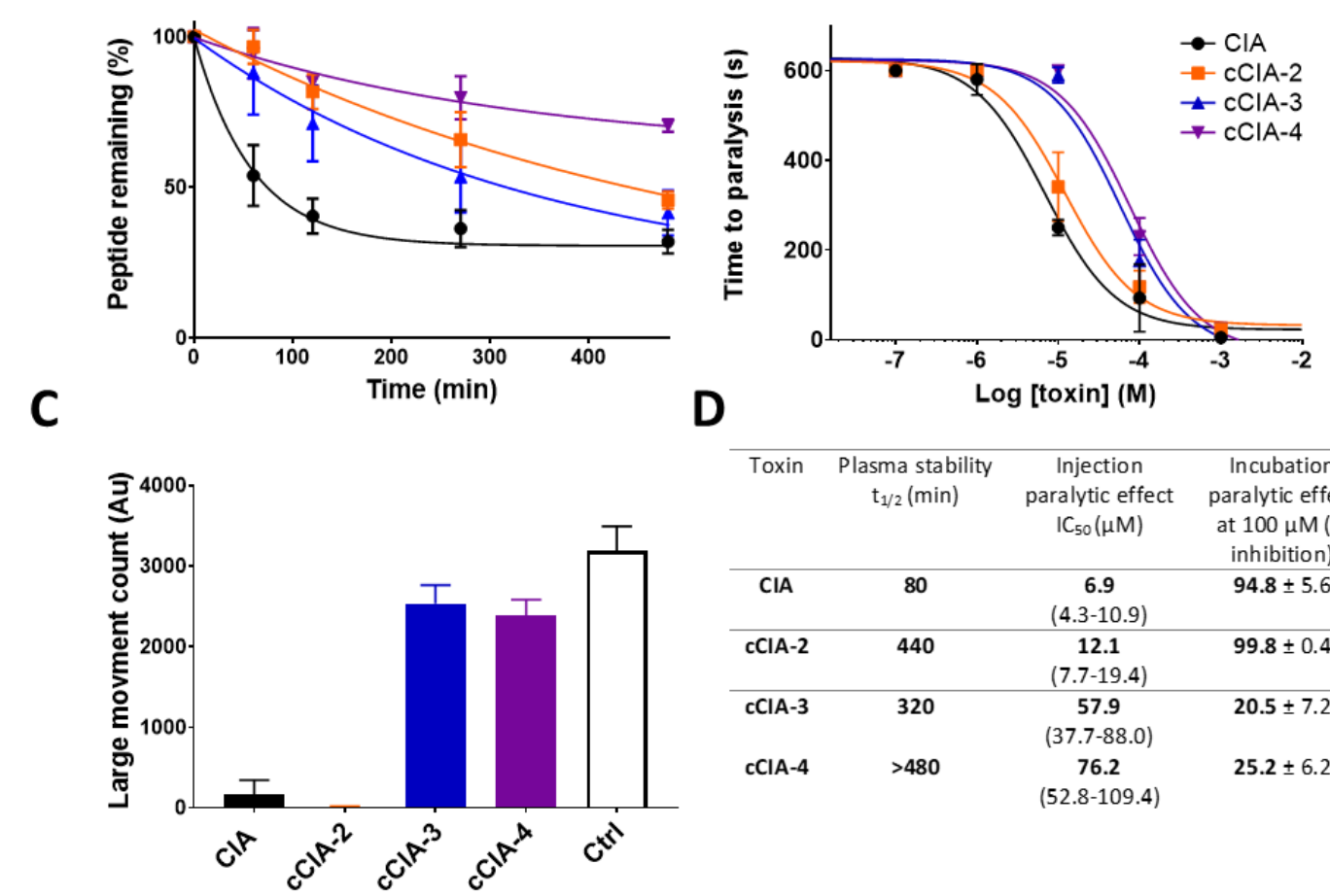

\begin{tabular}{|c|c|c|c|}
\hline Toxin & $\begin{array}{c}\text { Plasma stability } \\
t_{1 / 2}(\min )\end{array}$ & $\begin{array}{c}\text { Injection } \\
\text { paralytic effect } \\
\mathrm{IC}_{50}(\mu \mathrm{M})\end{array}$ & $\begin{array}{c}\text { Incubation } \\
\text { paralytic effect } \\
\text { at } 100 \mu \mathrm{M}(\% \\
\text { inhibition) }\end{array}$ \\
\hline CIA & 80 & $\begin{array}{c}6.9 \\
(4.3-10.9)\end{array}$ & $94.8 \pm 5.6$ \\
\hline cCIA-2 & 440 & $\begin{array}{c}12.1 \\
(7.7-19.4)\end{array}$ & $99.8 \pm 0.4$ \\
\hline CCIA-3 & 320 & $\begin{array}{c}\mathbf{5 7 . 9} \\
(37.7-88.0)\end{array}$ & $20.5 \pm 7.2$ \\
\hline cClA-4 & $>480$ & $\begin{array}{c}76.2 \\
(52.8-109.4)\end{array}$ & $25.2 \pm 6.2$ \\
\hline
\end{tabular}

Figure 4. Serum stability of CIA and CCIA analogues and paralytic effect of the cCIA analogues on zebrafish (Danio rerio). (A) Stability of CIA and cCIA analogues in human serum. Positive control: linear peptide, negative control: incubation in water. Points represent the mean of one measurement performed in triplicate. Error bars represent the S.D. (B) Doseresponse analysis of paralysis induced by intramuscular injection of conotoxins CIA and cCIA analogues in adult zebrafish. Experiment was performed in triplicate with a negative control (water injection). Points represent the mean of the triplicate. Error bars represent the S.D. (C) Large movement count over $1 \mathrm{~h}$ of Danio rerio larvae movement tracking after addition of the toxins into the water at a concentration of $100 \mu \mathrm{M}$. Each point represents the mean of measurements from six different larvae. Error bars represent the S.D. (D) Summary of results, $95 \%$ confidence intervals are in brackets. Symbol \pm indicates the standard deviation.

\section{Mouse muscle contraction assays \\ $\alpha$-CIA and analogues block nerve-evoked muscle contrac- tion}

When applied at nanomolar concentrations to isolated phrenic-nerve hemidiaphragm muscle preparation, CIA and cCIA analogues produced a concentration- and time-dependent reduction of the isometric twitch force evoked by nerve stimulation at $0.1 \mathrm{~Hz}$ (Figure 5A-B).

For the most active peptide (cCIA-3), the time required to block $50 \%$ of nerve evoked muscle contraction was $19.0 \pm$ $6.2 \min (\mathrm{n}=4)$, and a $40 \%$ recovery was obtained in $32.6 \pm$ $1.8 \min (\mathrm{n}=3)$ (data not shown), in agreement with muscletype nAChR blockade. The effect of all peptides was reversible upon washing the preparations with an extracellular medium free of $\alpha$-conotoxins. These results indicate that CIA and analogues are effective neuromuscular blockers, and are 2-3 fold more potent than the previously studied $\alpha \mathrm{C}$-PrXA, a highly specific and potent inhibitor of muscletype $\mathrm{nAChR}{ }^{24}$.

In order to confirm that cCIA-3 acts as a competitive antagonist at the muscle-type nAChR, we determined if an increase of evoked ACh release from nerve terminals could displace cCIA-3 from its nAChR binding site. Therefore, we used 3,4-diaminopyridine (3,4-DAP), which greatly increases quantal ACh release by reversibly blocking voltage- gated $\mathrm{K}^{+}$channels in motor nerve terminals ${ }^{25-27}$, which is used to treat certain forms of muscle weakness.

As shown in Figure 5C, cCIA-3 (16 nM) blocked the peak amplitude of nerve-evoked contraction by approximately $85 \%$, and this effect was $80 \%$ reversed upon addition of 3,4-DAP $(10 \mu \mathrm{M})$ to the medium (Figure 5C-D). Interestingly, when computing twitch tension-time integrals instead of peak amplitudes, the reversal was in the range of 96-98\%. This difference in values is explained by the fact that nerve-evoked contractions exhibit a prolonged time course in the presence of 3,4-DAP (shown in a comparison of the control and 3,4-DAP traces in Figure 5C). In conclusion, these data can be explained by a mechanism in which 3,4-DAP increases acetylcholine release from nerve terminals and the increased ACh displaces the cCIA-3 analogue from the muscle endplate nAChR, and thus strongly support our assumption that the peptide acts in a competitive manner on the muscle-type nAChR, in agreement with the described mode of action of $\alpha$-conotoxins.

Train-of-four (TOF) fade in the presence of conotoxins with muscle and dual muscle/ $\alpha 3 \beta 2$ selectivity

Train-of-four (TOF) stimulation is commonly used to monitor neuromuscular transmission when muscle relaxants are applied. A fade in muscle twitches (reduction of the twitch amplitude after repetitive nerve stimulation) is observed with non-depolarizing but not with depolarizing 
muscle relaxants ${ }^{28-30}$. Curare-like agents (competitive inhibitors of the muscle-type nAChR) that produce a non-depolarizing neuromuscular block at the neuromuscular junction are known to display a typical TOF fade, both in vitro and in vivo ${ }^{31-33}$. The TOF fade corresponds to the T4 / T1 ratio, where $\mathrm{T} 4$ and $\mathrm{T} 1$ are the fourth and first twitch tensions in the same train of four stimulations. The inhibition of the presynaptic facilitatory $\alpha 3 \beta 2 \mathrm{nAChR}$ autoreceptor at motor nerve terminals and the resulting inhibition of autofacilitatory ACh release has been suggested as an explanation for the train-of-four fade seen during a non-depolarizing neuromuscular block ${ }^{28,29}$. However, this hypothesis was recently challenged by using ligands with different selectivities for pre- and post-synaptic receptors ${ }^{34}$. Therefore, due to their original dual muscular $/ \alpha 3 \beta 2$ nAChRs antagonist property, it was of interest to determine whether $\alpha$-CIA and the cCIA analogues were able to produce TOF fade.

A

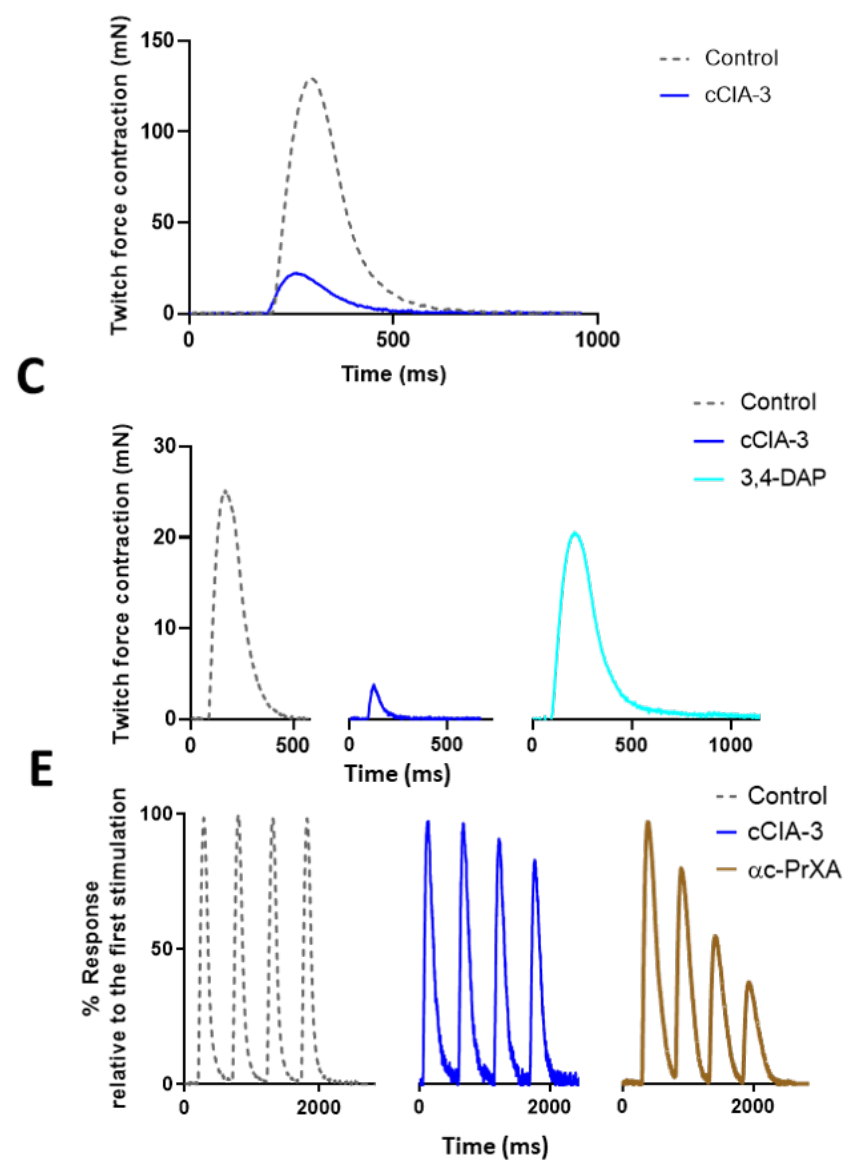

Under control conditions (in the absence of peptides), no TOF fade is observed as shown by the typical recordings (Figure 5E). Remarkably, when nerve-evoked contraction was inhibited about $76 \%$ by cCIA-3, no significant TOF fade was observed either. In contrast, a marked TOF fade was observed with the highly muscle-selective $\alpha \mathrm{C}$-PrXA peptide (no inhibitory activity at $\alpha 3 \beta 2$ ), already at approximately $45 \%$ neuromuscular block (Figure 5E). As shown in Figure $5 \mathrm{~F}$, TOF fadings were determined at different conotoxins concentrations. If a $50 \%$ decrease of TOF fade was measured with $\alpha \mathrm{C}$-PrXA (23nM), no significant effect was observed at any concentrations of the $\alpha$-CIA and cCIA analogues studied. Therefore, these data strongly argue against the common explanation of TOF fade, i.e. the blockade of $\alpha 3 \beta 2$ autoreceptors at the neuromuscular junction.

B
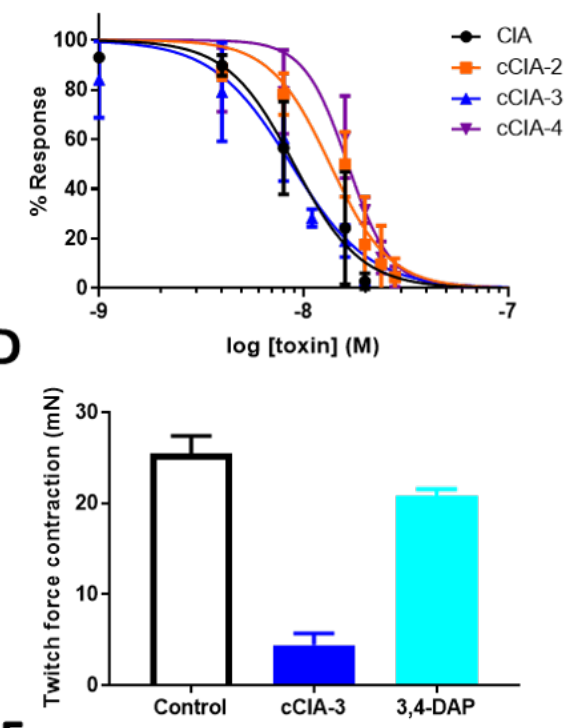

$\mathbf{F}$

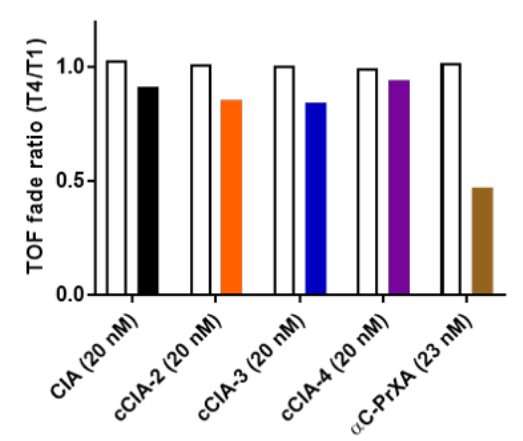

Fig. 5. In vivo mouse hemidiaphragm muscle recordings and TOF fade ratio of CIA and the cyclic analogues. (A) Typical twitch responses upon nerve stimulation $(0.1 \mathrm{~Hz})$ under control conditions and during the action of cCIA-3 (16 nM). (B) Concentration-response curves for CIA ( $\left.\mathrm{IC}_{50}=8.98 \mathrm{nM}\right), \mathrm{cCIA}-2\left(\mathrm{IC}_{50}=13.48 \mathrm{nM}\right), \mathrm{cCIA}-3\left(\mathrm{IC}_{50}=8.70 \mathrm{nM}\right), \mathrm{cCIA}-4$ (IC $\left.50=16.47 \mathrm{nM}\right)$. Data points represent the mean \pm S.D. of twitch responses from 1-9 nerve-muscle preparations, after 20-25 min toxin exposure, relative to the respective controls. (C) Isometric twitch tension recordings evoked by nerve stimulation ( $0.1 \mathrm{~Hz}$ ) on the same phrenic-nerve hemidiaphragm preparation under control conditions, following 30 min incubation with $16 \mathrm{nM}$ cCIA-3, and after 27 min of $10 \mu \mathrm{M}$ 3,4-DAP action. Note the different time course of twitch recordings between the control and after 3,4-DAP-treatment. (D) Data obtained in the same preparation and expressed as means \pm S.D. ( $n=14$ ) (E) Isometric tension developed during TOF nerve stimulation $(2 \mathrm{~Hz}$ ) under control conditions, and in the presence of cCIA-3 and $\alpha \mathrm{C}$-PrXA. Note 
the TOF fade in the presence of $\alpha \mathrm{C}$-PrXA. Signal amplitude is relative to the maximum response of each compounds (F) TOF fade ratio (T4/T1) in the presence of $\alpha$-CIA, cCIA analogues, and $\alpha \mathrm{C}$-PrXA. T4/T1 ratio in the presence of $\alpha$-CIA, cCIA analogues, and $\alpha \mathrm{C}$-PrXA. Note that a significant fade is only seen for PrXA. Control experiments are represented in white.

\section{Discussion}

Backbone cyclization has previously been reported to enhance stability and in some cases to improve the permeability of the cyclic analogue through biological membranes ${ }^{13-}$ 17. Considering the unusual dual activity of the $3 / 5 \alpha$-conotoxin CIA on muscle and neuronal nAChR $\alpha 3 \beta 2$ subtypes, we investigated the effect of backbone cyclization on its pharmacology and stability. During the cyclization process, a linker minimizing perturbations of the three-dimensional structure of a bioactive native toxin is highly desirable. Indeed, Clark et al. showed that an inappropriate linker can distort the structure by introducing strain to the peptide leading to a loss of bioactivity ${ }^{13,14}$. Therefore, based on the inter-termini spacing ( $9.8 \AA$ ), amino acid linkers with a length between 10 and $19 \AA ̊$ were chosen.

Overall conservation of the structure between CIA and its cyclic analogues was confirmed by NMR spectroscopy. Nevertheless, the linker length appeared to have a significant impact locally, particularly for residues 10-14 of CIA (Supplementary Table S1). cCIA-3 displays the lowest RMSD value and therefore has the most well-defined structure, and shows only one predominant conformation in the NMR spectra in contrast to the other two cyclic analogues.

Consistent with the NMR data, structural conservation of the cCIA analogues compared to the native CIA led to the conservation of the bioactivity towards muscle-type nAChRs at low nanomolar concentrations. However, the significant decrease in $\mathrm{K}_{\text {off }}$ values suggests stronger interaction of the cyclic analogues within one, or both, of the two orthosteric muscle $\mathrm{nAChR}$ binding sites. Considering the high sequence homology of $\alpha$-CIA with $\alpha$-MI and $\alpha-\mathrm{GI}, \alpha-\mathrm{CIA}$ is most likely binding at the $\alpha-\delta$ interface ${ }^{35,36}$. It has been demonstrated that the ACh binding pocket is mostly composed of hydrophobic residues that interact with residues of the two conotoxin loops formed by the disulfide bridges. Although, the linker is outside of these cysteine loops, the lower $\mathrm{K}_{\text {off }}$ values of cCIA-3 and cCIA-4 might be due to stronger hydrophobic interactions arising from the additional alanine residues in the linker compared to cCIA-2. Interestingly, and in contrast to our observations at the muscle nAChRs, dissociation rates from the neuronal $\alpha 3 \beta 2$ subtype were so fast that dissociation constants could not be determined with established protocols despite a strong potency increase at these subtypes. This raised the question of how exactly the native $\alpha$-CIA and the cyclic analogues bind to the $\alpha 3 \beta 2$ subtype. Indeed, allosteric modulators usually display very fast dissociation rates, however, functional competition binding experiments suggested a competitive binding of cCIA- 3 to the orthosteric $\alpha 3 \beta 2$ binding site and we can reasonably extend this hypothesis to cCIA-2, -4 and native $\alpha$-CIA toxin. Surprisingly, all of the cyclic analogues also displayed a significantly increased potency at the $\alpha 3 \beta 2$ subtypes, with cCIA-3 being the most potent with a 52 -fold decreased IC 50 value compared to native $\alpha$-CIA. The high RMSD value ( $4.28 \AA$ ) in the region of residues $13-17$ of cCIA3 (compared to the equivalent residues in CIA) might allow favorable structural changes further enhanced by the welldefined structures of cCIA-3 (0.29 Å over backbone atoms) compared to native $\alpha$-CIA (0.95 $\AA$ over backbone atoms) possibly facilitating toxin binding to the receptor and explaining the higher potency of cCIA- 3 at the $\alpha 3 \beta 2 \mathrm{nAChR}$ subtype.

Cyclization of $\alpha$-CIA lead to an improved stability towards enzymatic degradation, in agreement with previous published data on $\alpha$-conotoxin cyclization ${ }^{13-17}$. cCIA-4 was the most resistant to degradation in serum, exhibiting a serum half-life of more than eight hours (70\% remaining peptide), followed by cCIA-2, cCIA-3 and native CIA, which is degraded at least four times faster. Nevertheless, CIA and the cCIA analogues appear to be more readily degraded in serum than cVc1.1 and cMII, as shown in the study by Clark et al. ${ }^{13,14}$. Unlike Vc1.1 and MII conotoxins, CIA contains one arginine residue before the first cysteine residue, and one lysine residue in the second loop that can be cleaved by endopeptidases.

A visible paralyzing effect, resulting from the block of muscle-type nAChR, was observed when CIA or the cCIA analogues were injected intramuscularly into zebrafish. Paralysis activity of the conotoxins could also be monitored by movement tracking of zebrafish (Danio rerio) larvae, after incubation with the toxins in the tank water. Based on the inhibition values obtained by intramuscular injection, we performed the assay at a concentration of $100 \mu \mathrm{M}$ (higher doses would require large amounts of peptides). CIA and cCIAs showed a paralyzing effect when added into the swimming water of Danio rerio larvae in comparison to the control, with CIA and cCIA-2 being the most potent. cCIA-3 and cCIA-4 exhibited a weaker activity, which is consistent with the intramuscular injection data. Zebrafish (Danio rerio) might not have the required metabolic means to completely digest the native CIA and make it completely inactive.

Considering the unique capacity of $\alpha$-CIA and cCIAs to block both muscle-type and neuronal $\alpha 3 \beta 2$ subtype nAChRs, they represent a novel pharmacological tool to study the contribution of the $\alpha 3 \beta 2$ subtype neuromuscular transmission in the presence of neuromuscular blockers. Consistent with the electrophysiology data, CIA and its cyclic analogues block the phrenic nerve-evoked isometric twitch force in mouse hemidiaphragm muscles in the nanomolar range. The cCIA-3-induced block was reversed when increasing the quantal ACh release by 3,4-DAP, thus confirming the competitive binding evidenced by electrophysiological binding experiments.

A role of the pre-synaptic $\alpha 3 \beta 2$ nicotinic receptor in the TOF fade phenomenon has been proposed previously 34 . One of the persevering theories is that presynaptic $\alpha 3 \beta 2$ nicotinic receptors would increase the release of acetylcholine via a positive feedback mechanism to maintain the contraction at the same level following repeated nerve stimulation at the neuromuscular junction. Thus, the presynaptic $\alpha 3 \beta 2$ inhibition could explain the attenuated release of acetylcholine leading to nerve-evoked muscle contraction fade 37. This hypothesis was recently challenged by using ligands with different selectivities for pre- and post-synaptic receptors ${ }^{34}$ : it was found that, in in-vivo experiments, the TOF 
fade was clearly correlated with the administration of postsynaptic muscle-type antagonist such as $\alpha$-bungarotoxin or $\alpha$-conotoxin GI, while the $\alpha 3 \beta 2$ blocker DH $\beta E$ was shown to potentiate the TOF fade. Nevertheless, $\mathrm{DH} \beta \mathrm{E}$ is a non-selective neuronal receptors blocker, thus justifying the re-examination of the precise role of the presynaptic $\alpha 3 \beta 2$ subtype here. Considering their high potency and distinct selectivities to both muscle-type and neuronal $\alpha 3 \beta 2$ nAChRs, CIA and its cyclic analogues represent unique pharmacological tools to address this question. Surprisingly, neither CIA nor its cyclic analogues induced a visible TOF fade, in contrast to the muscle-specific $\alpha \mathrm{C}$-PrXA conotoxin. Hence, in contradiction to the generally accepted hypothesis that TOF fade results from a dual block of presynaptic $\alpha 3 \beta 2$ and postsynaptic muscle nAChRs, our data show that dual blockade of $\alpha 3 \beta 2$ and muscle-type nAChRs is able to prevent this phenomenon. Thus, the role of the $\alpha 3 \beta 2 \mathrm{nAChR}$ in neuromuscular transmission needs to be studied in more detail, and the cyclic CIA analogues could provide the necessary pharmacological tools.

\section{Experimental section}

\section{Chemical synthesis}

DMF, DIEA, ACN, TIS, TFA, piperidine and all others reagents were obtained from Sigma-Aldrich (Saint-Louis, MI, USA) or Merck (Darmstadt, Germany) and were used as supplied. Fmoc (L) amino acid derivatives and HATU were purchased from Iris Biotech (Marktredwitz, Germany). PS2-Chlorotrityl chloride resin (100-200 mesh, $1.6 \mathrm{mmol} / \mathrm{g}$ ) was purchased from Iris Biotech (Marktredwitz, Germany). The following side-chain protecting groups were used: Asn(Trt), Cys(Trt), His(Trt), Arg(Pbf), Cys(Acm), Lys(Boc), Ser(tBu). Peptides were manually synthesized using the Fmoc-based solid-phase peptide synthesis technique on a VWR (Radnor, PA, USA) microplate shaker. All Fmoc amino acids and HATU were dissolved in DMF to reach $0.5 \mathrm{M}$. The first amino acid was coupled onto the resin for $6 \mathrm{~h}$ in a $1 / 1$ (v/v) mix of DMF and DCM, with a 2.5-fold excess of amino acid and 5-fold excess of DIPEA followed by addition of methanol and further mixing for 15 min to cap any remaining reactive functionalities on the resin. The resin was washed with DMF, DCM, MeOH, and DMF. Fmoc deprotection was carried out with piperidine in DMF $(1 / 2 \mathrm{v} / \mathrm{v})$ twice for $3 \mathrm{~min}$. Subsequent amino acids were coupled onto 0.1 mmol of prepared resin (determined loading value 0.73 $\mathrm{mmol} / \mathrm{g}$ ) twice for $10 \mathrm{~min}$ using an amino acid/HATU/DIPEA ratio of 5:5:10 relative to resin loading. DMF was used for resin washing between deprotection and coupling steps. After chain assembly was complete, the terminal Fmoc group was removed and the resin washed with DMF and DCM. Cleavage of the peptide from the resin without affecting the side-chain protecting group was carried out in a reaction vessel and treated ten times with $10 \mathrm{~mL}$ of $1 \%$ TFA in DCM (v/v) for 5 min. Eluates were collected and combined into a round-bottomed flask then DCM and TFA were removed under vacuum and cold diethyl ether added to precipitate the peptide. The crude side-chain protected peptide was dissolved in DMF at a concentration of $2 \mathrm{mM}$ in a round-bottom flask. HATU was added to the solution to give a final concentration of $5 \mathrm{mM}$ and mixed for $30 \mathrm{~s}$. DIPEA was added to a final concentration of $10 \mathrm{mM}$, and the solution was stirred for $4 \mathrm{~h}$ at room temperature. DMF was removed under vacuum and residues were uptake in $\mathrm{ACN} / \mathrm{H}_{2} \mathrm{O}(1 / 1 \mathrm{v} / \mathrm{v})$ and freeze dried overnight. Side-chain (except acm) deprotection was carried out by adding 6.25 $\mathrm{mL}$ of TFA/TIS $/ \mathrm{H}_{2} \mathrm{O}(95 / 2.5 / 2.5 \mathrm{v} / \mathrm{v} / \mathrm{v})$ per $100 \mathrm{mg}$ of crude peptide and stirring the mixture for $2.5 \mathrm{~h}$ at room temperature. Crude peptides were purified by preparative RP-HPLC and pure fractions were combined and freeze-dried. A twostep oxidation procedure was then carried out. The first disulfide bridge is formed between the free cysteine residues CysII-CysIV by dissolving the peptide at $0.2 \mathrm{mM}$ in $50 \mathrm{mM}$ Tris-HCl buffer adjusted to $\mathrm{pH} 8$ and adding 7 equivalents of DTP at $10 \mathrm{mM}$ in $\mathrm{MeOH}$ dropwise. When the reaction was complete the reaction mixture was acidified to $\mathrm{pH} 3$ and loaded onto preparative RP-HPLC and pure fractions were combined. The second disulfide bridge CysI-CysIII was formed by deprotection/oxidation of the Acm protecting group directly on the combined pure fractions of the mono bridged intermediates by treatment with 20 equivalents of $10 \mathrm{mM}$ iodine in $\mathrm{H}_{2} \mathrm{O} / \mathrm{TFA} / \mathrm{ACN}(78 / 2 / 20 \mathrm{v} / \mathrm{v} / \mathrm{v})$. When the reaction was complete, the reaction mixture was quenched with $20 \mathrm{mM}$ ascorbic acid until total discoloration of the solution, acidified and purified by preparative RP-HPLC. The combined pure fractions were freeze-dried and their purity were confirmed by LC/ESI-MS. cCIA-2,-3,-4 peptides have been obtained with $6.3 \%, 7.5 \%$ and $5.4 \%$ yields respectively (purity $>95 \%$ ). The peptide content was estimated at $60 \%$ from dry weight.

\section{Mass spectrometry}

Solvents used for LC/MS were of HPLC grade. The LC/MS system consisted of a Waters (Milford, OH, USA) Alliance 2695 HPLC, coupled to a Waters Micromass ZQ spectrometer (electrospray ionization mode, ESI+). All the analyses were carried out using a Chromolith (Fontenay sous Bois, France) HighResolution RP-18e (4.6 x 25 mm, 15 nm-1.15 $\mu \mathrm{m}$ particle size, flow rate $3.0 \mathrm{~mL} / \mathrm{min}$ ) column. A flow rate of $3 \mathrm{~mL} / \mathrm{min}$ and a gradient of $0-100 \%$ B over $2.5 \mathrm{~min}$ for routine analyses and $0-30 \% \mathrm{~B}$ over $30 \mathrm{~min}$ for quality control of pure products were used. Solvent A: water $/ 0.1 \%$ $\mathrm{HCO}_{2} \mathrm{H}$; solvent $\mathrm{B}$ : ACN/0.1\% $\mathrm{HCO}_{2} \mathrm{H}$. UV detection was performed at $214 \mathrm{~nm}$. Electrospray mass spectra were acquired at a solvent flow rate of $200 \mu \mathrm{L} / \mathrm{min}$. Nitrogen was used for both the nebulizing and drying gas. The data were obtained in a scan mode ranging from 100 to $1000 \mathrm{~m} / \mathrm{z}$ or 250 to $1500 \mathrm{~m} / \mathrm{z}$ to in $0.7 \mathrm{~s}$ intervals.

Folded peptides were characterized using a Synapt G2-S high resolution MS system (Waters Corp., Milford, MA) equipped with an ESI source. Chromatographic separation was carried out at a flow rate of $0.4 \mathrm{~mL} / \mathrm{min}$ on an Acquity H-Class ultrahigh performance liquid chromatography (UPLC) system (Waters Corp., Milford, MA), equipped with a Kinetex C18 $100 \AA$ column $(100 \times 2.1 \mathrm{~mm}, 2.6 \mu \mathrm{m}$ particle size) from Phenomenex (France). The mobile phase consisted of water (solvent A) and ACN (solvent B) with both phases acidified by $0.1 \%(\mathrm{v} / \mathrm{v})$ formic acid. Mass spectra were acquired in the positive ionization mode.

\section{Preparative RP-HPLC}

Preparative RP-HPLC was run on a Gilson PLC 2250 Purification system (Villiers le Bel, France) instrument using a preparative column (Waters DeltaPak C18 Radial-Pak Cartridge, $100 \AA$, 40 x $100 \mathrm{~mm}, 15 \mu \mathrm{m}$ particle size, flow rate $50.0 \mathrm{~mL} / \mathrm{min}$ ). Solvent A was $0.1 \%$ TFA in water, and 
solvent B was $0.1 \%$ TFA in ACN. A gradient of $0-50 \%$ B over 50 min was used.

\section{Electrophysiological Recordings}

cDNAs encoding rat $\alpha 2, \alpha 3, \alpha 4, \alpha 6, \beta 2$ and $\beta 4$ nAChRs were provided by Jim Patrick (Baylor College of Medicine, Houston, TX, USA) and subcloned into the oocyte expression vector pNKS2. The rat $\alpha 6 / \alpha 3$ Chimera ${ }^{38,39}$ was generated by Gibson assembly in the pNKS2 vector. Fetal rat muscletype $(\alpha 1, \beta 1, \gamma, \delta)$ subunit cDNAs in pSPOoD were provided by Veit Witzemann (MPI for Medical Research, Heidelberg, Germany). Plasmids for expression of $\alpha 7, \alpha 9, \alpha 10$ and adult muscle-type $(\alpha 1, \beta 1, \varepsilon, \delta)$ nAChRs were a gift from David Adams (Illawara Health and Medical Research Institute, Wollongong University, Australia). Synthesized human muscle subunit cDNAs (Integrated DNA Technologies (IDT) (Coralville, IA, USA) and human $\alpha 9$ and $\alpha 10$ pCMV6-XL5 constructs (OriGene (Rockville, MD, USA)) were cloned in pT7TS. Human $\alpha 7$ in pMXT was provided from Prof. Jon Lindstrom (Uni. Pennsylvania, PA, USA). cRNA was synthesized from linearized plasmids with SP6 RNA polymerase using the mMessageMachine kit (Invitrogen, Thermo Fisher Scientific, USA). Xenopus laevis oocytes were kindly provided by Prof. Luis Pardo (MPI of Experimental Medicine, Göttingen), injected with 50-nL aliquots of cRNA $(0.5$ $\mu \mathrm{g} / \mu \mathrm{L})$, and kept at $16^{\circ} \mathrm{C}$ in filtered ND96 (96 mM NaCl, $2 \mathrm{mM} \mathrm{KCl}, 1 \mathrm{mM} \mathrm{CaCl}$, $1 \mathrm{mM} \mathrm{MgCl}$, 5 mM HEPES, pH 7.4) containing gentamicin $(5 \mu \mathrm{g} / \mathrm{mL})$.

Two-electrode voltage clamp recordings were performed 1-5 days after cRNA injection at a holding potential of -70 $\mathrm{mV}$. Pipettes were pulled from borosilicate glass and filled with $3 \mathrm{M} \mathrm{KCl}$. Resistances were below $1 \mathrm{M} \Omega$. Membrane currents were recorded using a Turbo Tec 05X Amplifier (npi electronic, Tamm, Germany) filtered at $200 \mathrm{~Hz}$ and digitized at $400 \mathrm{~Hz}$. CellWorks software was used for recording. The perfusion medium was automatically switched between ND96 with or without agonist (100 $\mu \mathrm{M}$ ACh) using a custom-made magnetic valve system. A fast and reproducible solution exchange ( $<300 \mathrm{~ms}$ ) for agonist application was achieved using a 50- $\mu \mathrm{L}$ funnel-shaped oocyte chamber combined with a fast solution flow $(150 \mu \mathrm{L} / \mathrm{s})$ fed through a custom-made manifold mounted immediately above the oocyte. ACh pulses were applied for $2 \mathrm{~s}$ at 4 min intervals. After each application, the cell was superfused for $54 \mathrm{~s}$ with agonist-free solution, and the flow was then stopped for $3 \mathrm{~min}$. Immediately at the beginning of this interval, peptide (prepared in filtered ND96 containing $0.1 \%$ BSA m/V) was mixed from a 10-fold stock into the static bath when responses of three consecutive agonist applications differed by less than $10 \%$. The use of BSA showed no change in toxin potency but produced more stable measurements at low toxin concentrations. ACh-evoked current peaks following peptide incubation were normalized to the ACh current peak before peptide exposure.

The analysis of the electrophysiological data was performed using GraphPad Prism version 8.0. Dose-response curves were fit to the data using the Hill equation: \% response $=$ Bottom $+($ Top-Bottom $) /\left(1+10^{\wedge}\left(\left(\log \mathrm{IC}_{50^{-}}\right.\right.\right.$ $\mathrm{X})^{*}$ HillSlope)) and constraints of $100 \%$ and $0 \%$ for Top and Bottom, respectively. Dissociation curves were fit to the data with the equation $\%$ response $=($ response $($ time 0$)-$ plateau $)^{*} \exp \left(-\mathrm{K}^{*}\right.$ time $)+$ plateau.
The functional analysis of competitive binding was performed as previously described ${ }^{40}$. Briefly, 2s ACh pulses were applied in $1 \mathrm{~min}$ intervals until stable responses were obtained. The perfusion was then stopped for $7 \mathrm{~min}$ for application of cCIA-3 (after $1 \mathrm{~min}$ ) and/or MII (after $4 \mathrm{~min}$ ) in the static bath. As a control, ND96 was applied instead of a peptide. All peak currents were normalized to the mean of the four stable ACh evoked peak currents before the peptide incubation.

All experiments were performed with oocytes from at least two different frogs.

NMR spectroscopy

Lyophilized synthetic peptides ( 1.5-2 mg) were resuspended in $90 \% \mathrm{H}_{2} \mathrm{O}: 10 \% \mathrm{D}_{2} \mathrm{O}$. 2D ${ }^{1} \mathrm{H}-{ }^{1} \mathrm{H}$ TOCSY, ${ }^{1} \mathrm{H}-{ }^{1} \mathrm{H}$ NOESY, ${ }^{1} \mathrm{H}-{ }^{1} \mathrm{H}$ DQF-COSY, ${ }^{1} \mathrm{H}-{ }^{15} \mathrm{~N}$ HSQC, and ${ }^{1} \mathrm{H}-{ }^{13} \mathrm{C}$ HSQC spectra were acquired at $290 \mathrm{~K}$ using a $600 \mathrm{MHz}$ AVANCE III NMR spectrometer (Bruker, Karlsruhe, Germany) equipped with a cryogenically cooled probe. All spectra were recorded with an interscan delay of $1 \mathrm{~s}$. NOESY spectra were acquired with mixing times of 200-250 ms, and TOCSY spectra were acquired with isotropic mixing periods of 80 ms. Two-dimensional spectra were collected over 4096 data points in the $\mathrm{f} 2$ dimension and 512 increments in the f1 dimension over a spectral width of $12 \mathrm{ppm}$. Standard Bruker pulse sequences were used with an excitation sculpting scheme for solvent suppression. The two-dimensional NOESY spectra of the cCIA analogues were automatically assigned and an ensemble of structures calculated using the program CYANA ${ }^{41}$. Torsion-angle restraints from TALOS+ were used in the structure calculations. The final structures were visualized using Pymol (The PyMOL Molecular Graphics System, Version 2.0 Schrödinger, LLC.), MOLMOL ${ }^{42}$ and UCSF Chimera ${ }^{43}$.

Monitoring of the paralysis effect after Injection into adult zebrafish(Danio rerio)

Sixty three adult male and female (2-5 months) zebrafish wild-type $\mathrm{AB}$ were maintained under standardized conditions and experiments were conducted in accordance with the European Communities council directive 2010/63, procedures were approved by Ethical Committee for Animal Experiment of Languedoc Roussillon $n^{\circ} 36$ (reference number: 2018040911129080 \#14665 v4). The AB wild-type zebrafish line has been obtained from ZIRC (Zebrafish International Resource Center, Oregon, USA; ID ZL1) and bred inhouse. Toxins were diluted in milli-Q water and $5 \mu \mathrm{L}$ of incremental doses were injected intramuscularly into adult zebrafish with a $10 \mu \mathrm{L}$ Neuros Syringe from Hamilton (Bonaduz, Switzerland). Each dose was repeated three times on three different fishes to determine error bars. The onset of paralysis was measured over a maximum observation time of 10 min. Paralysis was considered total when the fish went on its back. Negative control experiments were performed according to the same protocol by injecting water instead of toxins.

Monitoring of the paralysis effect after Incubation into zebrafish (Danio rerio) larvae swimming water

Experiments were conducted on 5-day-old larvae of zebrafish wild-type AB. Six larvae per toxin were placed in a 96-well plate and a controlled volume of swimming water was added. Small volumes of toxin were added to reach the 
final desired concentration of $100 \mu \mathrm{M}$. Immediately after incubation, the plate was placed in the movement tracking chamber. The movement of larvae was video captured and quantified using the Zebrabox infrared camera setup and tracking extension of the ZebraLab software system (Viewpoint Life Sciences, Canada). The integration period for movement data was set to $30 \mathrm{~min}$. Each time the animal speed goes above the small/large movement threshold, the large movement counter in incremented. Negative control experiments were performed according to the same protocol by adding water instead of toxins.

In vitro assays on isolated mouse nerve-muscle preparations

\section{Animals}

Twenty eight adult (14 male and 14 female) Swiss mice (Mus musculus, 2-5 months of age and 23-28 g of body weight), were purchased from Janvier Elevage (Le GenestSaint-Isle, France). Mice were acclimatized at the CEA animal facility for at least $48 \mathrm{~h}$ before experiments. Live animals were treated according to the European Community guidelines for laboratory animal handling and the guidelines established by the French Council on animal care "Guide for the Care and Use of Laboratory Animals" (EEC86/609 Council Directive - Decree 2001-131). Mice were housed four- to six-wise in cages with environmental enrichment, in a room with constant temperature and a standard light cycle of 12-h light/12-h darkness and had free access to water and food. All experimental procedures on mice were approved by the Animal Ethics Committee of the CEA and by the French General Directorate for Research and Innovation (project APAFIS\#2671$2015110915123958 v 4$ authorized to E. Benoit). Male and female mice were anesthetized by isoflurane (Aerrane ${ }^{\circledR}$, Baxter S.A., Lessines, Belgium) inhalation before being euthanized by dislocation of the cervical vertebrae.

\section{Recordings on isolated nerve-muscle preparations}

In vitro assays were performed on left phrenic-nerve hemidiaphragm muscle preparations quickly removed and mounted in a silicone-lined organ bath ( $4 \mathrm{~mL}$ capacity). Preparations were bathed in a Krebs-Ringer solution of the following composition: $150 \mathrm{mM} \mathrm{NaCl}, 5 \mathrm{mM} \mathrm{KCl}, 2 \mathrm{mM}$ $\mathrm{CaCl}_{2}, 1 \mathrm{mM} \mathrm{MgCl}$, $11 \mathrm{mM}$ glucose, and $5 \mathrm{mM}$ HEPES $(\mathrm{pH}$ 7.4), continuously superfused with pure $\mathrm{O}_{2}$ throughout the experiment at a constant temperature of $22^{\circ} \mathrm{C}$, unless otherwise indicated. For nerve-evoked isometric twitch tension measurements, the phrenic nerve was usually stimulated with a suction microelectrode (adapted to the diameter of the nerve) with supramaximal current pulses of 0.25 ms duration, at a frequency of $0.1 \mathrm{~Hz}$ delivered by the isolation unit of a stimulator (S-44 Grass Instruments, West Warwick, RI, USA). The hemidiaphragm tendons (at the rib side) were tightly anchored onto the silicone-coated bath with stainless pins, and the other tendon (central medial tendon) was attached via an adjustable stainless-steel hook to a FT03 isometric force transducer (Grass Instruments). The resting tension was monitored for each preparation tested and adjusted with a mobile micrometer stage allowing variations of muscle length in order to obtain maximal contraction amplitude in response to motor nerve stimulation. Once maximal contraction was obtained, the resting tension was fixed, and monitored during the whole duration of the experiment. Signals from the isometric transducer were amplified, collected, and digitized with the aid of a computer equipped with an Axon ${ }^{\mathrm{TM}}$ Digidata-1550B A/D (interface board low noise acquisition systemplus hum silencer ${ }^{\mathrm{TM}}$ ), using the PClamp/Axoscope 10.7 version software (Axon Instruments, Molecular Devices Inc., Sunnyvale, CA, USA).

In some experiments a Train-Of-Four (TOF) stimuli was delivered to the phrenic nerve trunk at a frequency of $2 \mathrm{~Hz}$ for $2 \mathrm{~s}$, at a train rate of $0.033 \mathrm{~Hz}$. The ratio of muscle tension developed in the mouse hemidiaphragm by the fourth to the first stimulus was evaluated [T(4) /T(1)] at different peptide concentrations.

\section{Statistical analysis}

Data are presented as means \pm standard deviations (S.D.) of $\mathrm{n}$ different experiments. Differences between values were tested using the parametric two-tailed Student's $t$-test (either paired samples for comparison within a single population or unpaired samples for comparison between two independent populations) or the Kolmogorov-Smirnov twosample test. Differences were considered significant when $P<0.05$.

\section{Serum stability assay}

Human AB serum (VWR, Fontenay-sous-Bois, France) was centrifuged at $12000 \mathrm{~g}$ for $10 \mathrm{~min}$ for the removal of the lipid component. Supernatant was taken out and incubated for $15 \mathrm{~min}$ at $37^{\circ} \mathrm{C}$ before the assay. All peptides were tested at a final concentration of $30 \mu \mathrm{M}$ after dilution in serum (water for negative control). The incubation time points were 1 , 2,4 and $8 \mathrm{~h}$ at $37^{\circ} \mathrm{C}$. Controls and test peptides were incubated in parallel at each time point. Serum proteins were denatured by quenching with $40 \mu \mathrm{L}$ of $6 \mathrm{M}$ urea $(10 \mathrm{~min}, 4$ ${ }^{\circ} \mathrm{C}$ ), followed by the precipitation of proteins with an addition of $40 \mu \mathrm{L}$ of $20 \%$ trichloroacetic acid $\left(10 \mathrm{~min}, 4^{\circ} \mathrm{C}\right)$. These solutions were then centrifuged at $12000 \mathrm{~g}$ for 10 min. $100 \mu \mathrm{L}$ of supernatant was taken out at each time point. Chromatographic separation was carried out at a flow rate of $0.4 \mathrm{~mL} / \mathrm{min}$ on an Acquity H-Class ultrahigh performance liquid chromatography (UPLC) system (Waters, Corp., Milford, MA, United States), equipped with a Kinetex C18 100A column (100 $\mathrm{mm} \times 2.1 \mathrm{~mm}, 2.6 \mathrm{~mm}$ particle size) from Phenomenex (France). The mobile phase consisted of water (solvent A) and ACN (solvent B) with both phases acidified by $0.1 \%(\mathrm{v} / \mathrm{v})$ formic acid and gradient was $0-80 \% \mathrm{~B}$ in 10 min. Mass spectra were acquired in the positive ionization mode. The elution time for each peptide was determined by the zero-time point. The stability at each time point was calculated as the area of the serum treated peptide peak on RPHPLC at $214 \mathrm{~nm}$ as percentage of the area of the $0 \mathrm{~h}$ serum treated peptides. Controls were an eight-residue linear peptide incubated in serum for the positive control and incubated in water for the negative control. Each experiment was performed in triplicate.

\section{ASSOCIATED CONTENT}

Supporting Information. Additional figures illustrating binding assays and chemical synthesis as well as a structural statistics NMR table. This material is available free of charge via the Internet at http://pubs.acs.org.

\section{AUTHOR INFORMATION}

\section{Corresponding Author}


*Email: sebastien.dutertre@umontpellier.fr

\section{Author Contributions}

J.G. and S.D. conceived and led the study. J.G. performed peptide chemistry cyclisation, stability assays and zebrafish experiments, with input from S.D., C.E., A.F., H.M.O.M. Y.H. and A.D. carried out the electrophysiological recordings, with input from A.N. E.R.J.E. and C.S. performed the NMR experiments and analyses, with input from D.T.W. and N.L.D. M.A. and J.M. performed in vitro assays and recordings on isolated mouse nervemuscle preparations, with input from D.S. J.G. wrote the manuscript with input from all authors.

†J.G. and Y. H. contributed equally to this work.

\section{Notes}

${ }^{\psi}$ Please note that different IC $_{50}$ values of native CIA were found in a previous study ${ }^{18}$. We determined that the use of BSA in the conotoxin dilutions likely reduced the non-specific binding and resulted in higher potencies.

\section{ACKNOWLEDGMENT}

This work was supported by the French Ministry of Higher Education, Research and Innovation (PhD scholarship to J.G.), the French National Research Agency (ANR-16-CE34-0002 to S.D.) and a grant of the DFG (GRK 2338) to A.N. We thank Pranavkumar Shadamarshan for help with the oocyte recordings and Han Shen Tae and David Adams (Illawara Health and Medical Research Institute, Wollongong University, Australia) for subcloning and providing nAChR cDNAs.

\section{ABBREVIATIONS}

Acm, acetamidomethyl; ACN, acetonitrile; Boc, tert-butoxycarbonyle; DCM, Dichloromethane; DIPEA, diisopropylethylamine; DMF, $N, N^{\prime}$-dimethylformamide; DTP, 2,2'-Dithiopyridine; ESI-MS, electrospray ionization mass spectrometry; Fmoc, fluorenylmethoxycarbonyl; HATU, 1[Bis(dimethylamino)methylene]-1 $H$-1,2,3-triazolo[4,5- $b]$ pyridinium 3-oxid hexafluorophosphate; LC/MS, liquid chromatography/mass spectrometry; $\mathrm{MeOH}$, methanol; nAChR, nicotinic acetylcholine receptor; NMR, nuclear magnetic resonance; Pbf, pentamethyl-dihydrobenzofuran-5-sulfonyl; RP-HPLC, reversed-phase high performance liquid chromatography; SPPS, solid-phase peptide synthesis; t-Bu, tert-butyl;TFA, trifluoroacetic acid; TIS, triisopropylsilane; Tris, 2-Amino-2-(hydroxymethyl)propane-1,3diol;Trt, trityl; UV, ultra-violet.

\section{REFERENCES}

(1) Lewis, R. J.; Garcia, M. L. Therapeutic Potential of Venom Peptides. Nat Rev Drug Discov 2003, 2 (10), 790-802. https://doi.org/10.1038/nrd1197.

(2) Puillandre, N.; Duda, T. F.; Meyer, C.; Olivera, B. M.; Bouchet, P. One, Four or 100 Genera? A New Classification of the Cone Snails. J Molluscan Stud 2015, $\quad 81 \quad$ (1), $1-23$. https://doi.org/10.1093/mollus/eyu055.

(3) Davis, J.; Jones, A.; Lewis, R. J. Remarkable Interand Intra-Species Complexity of Conotoxins Revealed by LC/MS. Peptides 2009, 30 (7), 1222-
1227. tides.2009.03.019.

https://doi.org/10.1016/j.pep-

Prashanth, J. R.; Brust, A.; Jin, A.-H.; Alewood, P. F.; Dutertre, S.; Lewis, R. J. Cone Snail Venomics: From Novel Biology to Novel Therapeutics. Future Med Chem 2014, 6 (15), 1659-1675. https://doi.org/10.4155/fmc.14.99.

Akondi, K. B.; Muttenthaler, M.; Dutertre, S.; Kaas, Q.; Craik, D. J.; Lewis, R. J.; Alewood, P. F. Discovery, Synthesis, and Structure-Activity Relationships of Conotoxins. Chem. Rev. 2014, 114 (11), 5815-5847.

https://doi.org/10.1021/cr400401e.

Giribaldi, J.; Dutertre, S. $\alpha$-Conotoxins to Explore the Molecular, Physiological and Pathophysiological Functions of Neuronal Nicotinic Acetylcholine Receptors. Neuroscience Letters 2018, 679, 24-34.

https://doi.org/10.1016/j.neulet.2017.11.063. Lebbe, E. K. M.; Peigneur, S.; Wijesekara, I.; Tytgat, J. Conotoxins Targeting Nicotinic Acetylcholine Receptors: An Overview. Mar Drugs 2014, 12 (5), 2970-3004.

https://doi.org/10.3390/md12052970.

Albuquerque, E. X.; Pereira, E. F. R.; Alkondon, M.; Rogers, S. W. Mammalian Nicotinic Acetylcholine Receptors: From Structure to Function. Physiological Reviews 2009, 89 (1), 73-120. https://doi.org/10.1152/physrev.00015.2008.

Lau, J. L.; Dunn, M. K. Therapeutic Peptides: Historical Perspectives, Current Development Trends, and Future Directions. Bioorganic \& $\mathrm{Me}$ dicinal Chemistry 2018, 26 (10), 2700-2707. https://doi.org/10.1016/j.bmc.2017.06.052.

Sato, A. K.; Viswanathan, M.; Kent, R. B.; Wood, C. R. Therapeutic Peptides: Technological Advances Driving Peptides into Development. Current Opinion in Biotechnology 2006, 17 (6), 638-642. https://doi.org/10.1016/j.copbio.2006.10.002.

Ovadia, O.; Linde, Y.; Haskell-Luevano, C.; Dirain, M. L.; Sheynis, T.; Jelinek, R.; Gilon, C.; Hoffman, A. The Effect of Backbone Cyclization on PK/PD Properties of Bioactive Peptide-Peptoid Hybrids: The Melanocortin Agonist Paradigm. Bioorganic \& Medicinal Chemistry 2010, 18 (2), 580-589. https://doi.org/10.1016/j.bmc.2009.12.010.

(12) Wang, C. K.; Craik, D. J. Designing Macrocyclic Disulfide-Rich Peptides for Biotechnological Applications. Nature Chemical Biology 2018, 14 (5), 417-427. https://doi.org/10.1038/s41589-0180039-y.

Clark, R. J.; Jensen, J.; Nevin, S. T.; Callaghan, B. P.; Adams, D. J.; Craik, D. J. The Engineering of an Orally Active Conotoxin for the Treatment of Neuropathic Pain. Angewandte Chemie International Edition 2010, 49 (37), 6545-6548. https://doi.org/10.1002/anie.201000620.

Clark, R. J.; Fischer, H.; Dempster, L.; Daly, N. L.; Rosengren, K. J.; Nevin, S. T.; Meunier, F. A.; 
Adams, D. J.; Craik, D. J. Engineering Stable Peptide Toxins by Means of Backbone Cyclization: Stabilization of the $\alpha$-Conotoxin MII. Proc Natl Acad Sci U S A 2005, 102 (39), 13767-13772. https://doi.org/10.1073/pnas.0504613102.

(15) Halai, R.; Callaghan, B.; Daly, N. L.; Clark, R. J.; Adams, D. J.; Craik, D. J. Effects of Cyclization on Stability, Structure, and Activity of $\alpha$-Conotoxin RgIA at the $A 9 \alpha 10$ Nicotinic Acetylcholine Receptor and GABA(B) Receptor. J. Med. Chem. 2011, 54 (19), https://doi.org/10.1021/jm201060r.

(16) Armishaw, C. J.; Jensen, A. A.; Balle, L. D.; Scott, K. C. M.; Sørensen, L.; Strømgaard, K. Improving the Stability of $\alpha$-Conotoxin AuIB Through N-to-C Cyclization: The Effect of Linker Length on Stability and Activity at Nicotinic Acetylcholine Receptors. Antioxidants \& Redox Signaling 2011, 14 (1), 6576. https://doi.org/10.1089/ars.2010.3458.

(17) Lovelace, E. S.; Armishaw, C. J.; Colgrave, M. L.; Wahlstrom, M. E.; Alewood, P. F.; Daly, N. L.; Craik, D. J. Cyclic MrIA: A Stable and Potent Cyclic Conotoxin with a Novel Topological Fold That Targets the Norepinephrine Transporter. J. Med. Chem. 2006, 49 (22), 6561-6568. https://doi.org/10.1021/jm060299h.

(18) Giribaldi, J.; Wilson, D.; Nicke, A.; El Hamdaoui, Y.; Laconde, G.; Faucherre, A.; Moha Ou Maati, H.; Daly, N.; Enjalbal, C.; Dutertre, S. Synthesis, Structure and Biological Activity of CIA and CIB, Two $\alpha$-Conotoxins from the Predation-Evoked Venom of Conus catus. Toxins 2018, 10 (6), 222. https://doi.org/10.3390/toxins10060222.

(19) Carpino, L. A.; Han, G. Y. 9-Fluorenylmethoxycarbonyl Function, a New Base-Sensitive AminoProtecting Group. Journal of the American Chemical Society 1970, 92 (19), 5748-5749. https://doi.org/10.1021/ja00722a043.

(20) Barlos, K.; Chatzi, O.; Gatos, D.; Stavropoulos, G. 2Chlorotrityl Chloride Resin. Studies on Anchoring of Fmoc-Amino Acids and Peptide Cleavage. Int. J. Pept. Protein Res. 1991, 37 (6), 513-520.

(21) Cheneval, O.; Schroeder, C. I.; Durek, T.; Walsh, P.; Huang, Y.-H.; Liras, S.; Price, D. A.; Craik, D. J. Fmoc-Based Synthesis of Disulfide-Rich Cyclic Peptides. J. Org. Chem. 2014, 79 (12), 5538-5544. https://doi.org/10.1021/jo500699m.

(22) Wüthrich, K. NMR of Proteins and Nucleic Acids; The George Fisher Baker Non-Resident Lectureship in Chemistry at Cornell University; Wiley: New York, 1986.

(23) Shen, Y.; Delaglio, F.; Cornilescu, G.; Bax, A. TALOS+: A Hybrid Method for Predicting Protein Backbone Torsion Angles from NMR Chemical Shifts. J Biomol NMR 2009, 44 (4), 213-223. https://doi.org/10.1007/s10858-009-9333-z.

(24) Jimenez, E. C.; Olivera, B. M.; Teichert, R. W. ACConotoxin PrXA: A New Family of Nicotinic Acetylcholine Receptor Antagonists. Biochemistry
2007, $46 \quad$ (30), 8717-8724. https://doi.org/10.1021/bi700582m.

(25) Molgo, J. Effects of Aminopyridines on Neuromuscular Transmission. In Aminopyridines and Similarly Acting Drugs: Effects on Nerves, Muscles and Synapses; Elsevier, 1982; pp 95-116. https://doi.org/10.1016/B978-0-08-0280004.50015-4.

(26) Molgó, J.; Lemeignan, M.; Guerrero, S. Facilitatory Effects of 4-Aminopyridine on Strontium-Mediated Evoked and Delayed Transmitter Release from Motor Nerve Terminals. European Journal of Pharmacology 1982, 84 (1-2), 1-7. https://doi.org/10.1016/0014-2999(82)901509.

(27) Sanders, D. B.; Juel, V. C.; Harati, Y.; Smith, A. G.; Peltier, A. C.; Marburger, T.; Lou, J.; Pascuzzi, R. M.; Richman, D. P.; Xie, T.; Demmel, V.; Jacobus, L. R.; Aleš, K. L.; Jacobus, D. P.; The Dapper Study Team. 3,4-diaminopyridine Base Effectively Treats the Weakness of Lambert-Eaton Myasthenia. Muscle Nerve 2018, 57 (4), 561-568. https://doi.org/10.1002/mus.26052.

(28) Jonsson, M.; Gurley, D.; Dabrowski, M.; Larsson, O.; Johnson, E. C.; Eriksson, L. I. Distinct Pharmacologic Properties of Neuromuscular Blocking Agents on Human Neuronal Nicotinic Acetylcholine Receptors: A Possible Explanation for the Train-of-Four Fade. Anesthesiology 2006, 105 (3), 521-533. https://doi.org/10.1097/00000542200609000-00016.

(29) Fagerlund, M. J.; Eriksson, L. I. Current Concepts in Neuromuscular Transmission. British Journal of Anaesthesia 2009, 103 (1), 108-114. https://doi.org/10.1093/bja/aep150.

(30) Tajima, T.; Amaya, J.; Katayama, K.; Koizumi, T. Difference of Train-of-Four Fade Induced by Nondepolarizing Neuromuscular Blocking Drugs: A Theoretical Consideration on the Underlying Mechanisms. J Anesth 1995, 9 (4), 333-337. https://doi.org/10.1007/BF02479947.

(31) Cheah, L. S.; Gwee, M. C. E. Train-Of-Four Fade During Neuromuscular Blockade Induced by Tubocurarine, Succinylcholine or $\alpha$-Bungarotoxin in the Rat Isolated Hemidiaphragm. Clin Exp Pharmacol Physiol 1988, 15 (12), 937-943. https://doi.org/10.1111/j.1440-

1681.1988.tb01039.x.

(32) Robbins, R.; Donati, F.; Bevan, D. R.; Bevan, J. C. Differential Effects of Myoneural Blocking Drugs on Neuromuscular Transmission in Infants. British Journal of Anaesthesia 1984, 56 (10), 10951099. https://doi.org/10.1093/bja/56.10.1095.

(33) Baird, W. L. M.; Bowman, W. C.; Kerr, W. J. Some Actions of Org NC45 and of Edrophonum in the Anaesthetized Cat and in Man. British Journal of Anaesthesia 1982, 54 (4), 375-385. https://doi.org/10.1093/bja/54.4.375. 
(34) Nagashima, M.; Yasuhara, S.; Martyn, J. A. J. Trainof-Four and Tetanic Fade Are Not Always a Prejunctional Phenomenon as Evaluated by Toxins Having Highly Specific Pre- and Postjunctional Actions: Anesthesia \& Analgesia 2013, 116 (5), 994-1000. https://doi.org/10.1213/ANE.0b013e31828841 e3.

(35) Bren, N.; Sine, S. M. Hydrophobic Pairwise Interactions Stabilize $\alpha$-Conotoxin MI in the Muscle Acetylcholine Receptor Binding Site. J. Biol. Chem. 2000, 275 (17), 12692-12700. https://doi.org/10.1074/jbc.275.17.12692.

(36) Ning, J.; Li, R.; Ren, J.; Zhangsun, D.; Zhu, X.; Wu, Y.; Luo, S. Alanine-Scanning Mutagenesis of $\alpha$-Conotoxin GI Reveals the Residues Crucial for Activity at the Muscle Acetylcholine Receptor. Marine Drugs 2018, $16 \quad$ (12), 507. https://doi.org/10.3390/md16120507.

(37) Bowman, W. C.; Prior, C.; Marshall, I. G. Presynaptic Receptors in the Neuromuscular Junction. Ann NY Acad Sci 1990, 604 (1 Presynaptic R), 69-81. https://doi.org/10.1111/j.17496632.1990.tb31983.x.

(38) Kuryatov, A.; Olale, F.; Cooper, J.; Choi, C.; Lindstrom, J. Human $\alpha 6$ AChR Subtypes: Subunit Composition, Assembly, and Pharmacological Responses. Neuropharmacology 2000, 39 (13),
2570-2590. https://doi.org/10.1016/s00283908(00)00144-1.

(39) McIntosh, J. M.; Azam, L.; Staheli, S.; Dowell, C.; Lindstrom, J. M.; Kuryatov, A.; Garrett, J. E.; Marks, M. J.; Whiteaker, P. Analogs of $\alpha$-Conotoxin MII Are Selective for $\alpha 6$-Containing Nicotinic Acetylcholine Receptors. Mol. Pharmacol. 2004, 65 (4), 944-952. https://doi.org/10.1124/mol.65.4.944.

(40) Ellison, M.; McIntosh, J. M.; Olivera, B. M. $\alpha$-Conotoxins ImI and ImII: SIMILAR A7 NICOTINIC RECEPTOR ANTAGONISTS ACT AT DIFFERENT SITES. J. Biol. Chem. 2003, 278 (2), 757-764. https://doi.org/10.1074/jbc.M204565200.

(41) Güntert, P. Automated NMR Structure Calculation with CYANA. Methods Mol. Biol. 2004, 278, 353378. https://doi.org/10.1385/1-59259-8099:353.

(42) Koradi, R.; Billeter, M.; Wüthrich, K. MOLMOL: A Program for Display and Analysis of Macromolecular Structures. J Mol Graph 1996, 14 (1), 51-55.

(43) Pettersen, E. F.; Goddard, T. D.; Huang, C. C.; Couch, G. S.; Greenblatt, D. M.; Meng, E. C.; Ferrin, T. E. UCSF Chimera?A Visualization System for Exploratory Research and Analysis. J. Comput. Chem. 2004, 25 (13), 1605-1612. https://doi.org/10.1002/jcc.20084. 
Insert Table of Contents artwork here

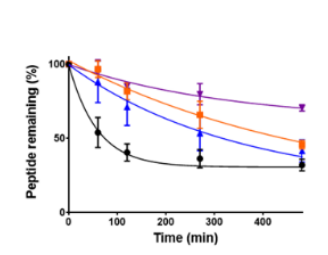

Improved stability
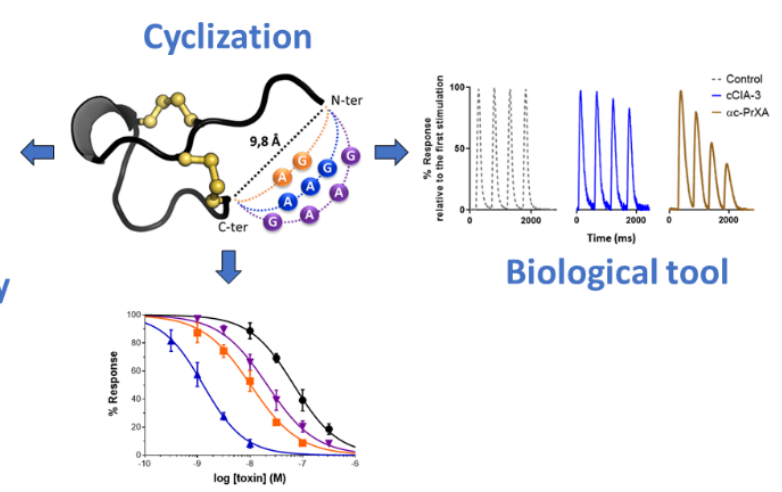

Improved activity 